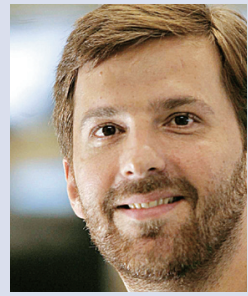

Daniel Piza OESP daniel.piza@grupoestado.com.br

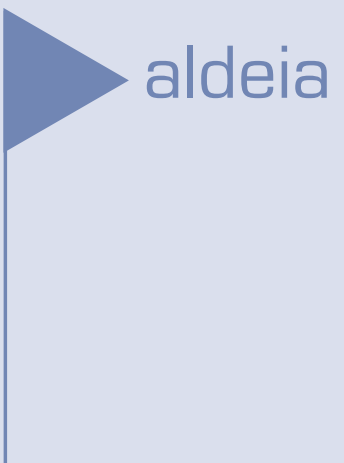

\title{
A polêmica do sucesso
}

\section{COMO EM TANTOS OUTROS TEMAS, O DEBATE BRASILEIRO SOBRE O SUCESSO SE DIVIDE EM DUAS CORRENTES ANTAGÔNICAS, SENTIMENTAIS, QUE MAL CONSEGUEM CONVERSAR ENTRE SI E, NO FUNDO, SÃO MUITO MAIS PARECIDAS DO QUE PENSAM}

Ou o sucesso é invejado, menosprezado, atribuído a causas menos nobres (sorte, malandragem, aparência), ou é tido como comprovação absoluta de mérito, de que os críticos estavam errados etc. Digamos que tal polêmica não se pode chamar de bem-sucedida.

Tom Jobim tem aquela frase famosa sobre o fato de que fazer sucesso no Brasil é "uma ofensa pessoal", uma espécie de pecado. Ele disse isso porque os patrulheiros de sempre o acusaram de "entreguismo" por vender os direitos de sua linda canção "Águas de março" para um comercial da Coca-Cola, essa multinacional imperialista. Lembro também quando o jogador Ronaldo, aquele que seria apenas um "fenômeno de marketing", comprou um Ferrari e muitos o criticaram por esse gesto de ostentação. Era preferível fingir que não tinha tanto dinheiro...

Mas há pessoas que não têm o valor historicamente reconhecido de Tom Jobim e Ronaldo e que acham que seu sucesso deveria deixá-las imunes a críticas. Penso em Paulo Coelho, que se intitula o "maior intelectual do Brasil", mas não consegue esconder o ressentimento de nunca ter recebido um prêmio literário realmente prestigioso em parte nenhuma do mundo. Ou penso nas pessoas que dizem fazer sucesso "lá fora" - de maestros a estilistas, de cineastas a cantores - e, portanto, deveriam ser recebidas nos aeroportos brasileiros com tapete vermelho e chuva de arroz.

Há aí a velha mania de país colonizado. Se Tropa de elite ganha prêmio em Berlim, tudo o que motivou os (raros) ataques dos críticos brasileiros não passou de má-vontade. Mas aí fica a pergunta: qual acusação pesa contra a crítica estrangeira, de publicações sérias como Variety e New Yorker, que, em sua maioria, também apontou defeitos graves no filme? Será que foi também por não gostar de quem faz sucesso? Caetano Veloso é outro que sempre que é criticado opta por xingar o crítico. Há um tom indiscutivelmente infantil nesses resmungos da classe artística.

Isso não significa que não é preciso resgatar o que costumo chamar de capacidade de admiração. Quem aprecia artes e esportes precisa ter um olhar interpretativo, não discriminatório, $e$ tentar entender por que algo agrada a tanta gente, e se isso é duradouro ou não. Érico Veríssimo e Jorge Amado, por exemplo, não são autores do porte de Machado de Assis e Guimarães Rosa, mas são criadores de tramas e personagens que merecem aplausos, até por ser esse um dom escasso entre escritores nacionais. Sucesso não condena nem santifica. $\boldsymbol{\star}$ 